\title{
Effect of four feeding rations on the growth performance of african giant catfish Heterobranchus bidorsalis fingerlings
}

\author{
Ayokanmi Adekunle DADA \\ National Institute for Freshwater Fisheries Research, P.M.B. 6006, New-Bussa, Niger State, Nigeria. \\ Present address: Department of Fisheries and Aquaculture Technology, Federal University of Technology, \\ Akure, Ondo State, Nigeria. \\ *Corresponding author, E-mail: dadaayokanmi@yahoo.com
}

\begin{abstract}
Feed ration is one of the important variables considered for the improvement in production of fish. The effects of four feeding rations on growth performance of Heterobranchus bidorsalis fingerlings were investigated for 7 weeks. The specific growth rate (SGR) at $4.0 \%$ feed ration was significantly higher than $10.0 \%$ feed ration, and there was no significant difference in SGR between $4.0 \%, 6.0 \%$ and $8.0 \%$. The growth performance was best at $6.0 \%$ feeding ration while the best feed utilization was obtained at $4.0 \%$ feeding ration with no significant difference $(\mathrm{P}>0.05)$ between the fish fed at $4.0 \%$ and $6.0 \%$ feeding rations. Based on the results, an intermediate feeding ration between $4.0 \%$ and $6.0 \%$ body weight per day is ideal for adequate growth and development of $H$. bidorsalis fingerling during culture period.
\end{abstract}

(C) 2012 International Formulae Group. All rights reserved.

Keywords: Heterobranchus bidorsalis, Survival, growth performance, feed utilization.

\section{INTRODUCTION}

The success of fish farming depends on maximizing production with minimum feed cost (Abdel-Hakim et al., 2009). The economic success of artificial feed depends upon appropriate feeding regime. Inappropriate feeding practices often lead to over feeding, pollution and higher production cost, while inadequate feeding may lead to stunted growth with high mortalities (Eroldogan et al., 2006). Knowledge of feeding rate and protein concentration is necessary to select appropriate feed quantity for a particular age group (Le et al., 2012).
Heterobranchus bidorsalis is a catfish with remarkable fast growth rate and commands a very good commercial value in Nigeria markets. There is paucity of data on the optimum feeding rate for this species. According to Abdelghany and Ahmad (2002) fish growth rate is directly related to ration level. The amount of feed consumed, age, body size and temperature are the most important factors that limit maximum growth of fish and prawn (Le et al., 2012; Zikria, 2012 ). 
Many studies have been conducted on effect of feeding rate on fish growth ( Rad et al., 2003; Abdel-Hakim et al., 2009; Wunderlich et al., 2011). Hongendoorn (1981) suggested $10 \%$ of the live body weight per day for C. gariepinus $(0.85 \mathrm{~g})$. Santiago et al. (1987) in their study recommended maximum feeding rate at $45 \%$ of the live body weight for Oreochromis niloticus fry $(0.01 \mathrm{~g})$. Desilva and Anderson (1995) recommended feeding at $50 \%$ of body weight per day for fry of channel catfish Ictalurus punctatus., while Dada et al. (2001) recommended feeding at $40 \%$ of the live body weight for $H$. bidorsalis $(0.03 \mathrm{~g})$. Based on the assertion that feeding rate varies with the species, size and age, and environmental factors, the present study was conducted to determine the effects of different feeding rations on the growth and food utilization of $H$. bidorsalis fingerlings.

\section{MATERIALS AND METHODS \\ Collection and acclimatization of experimental fish}

One hundred and eighty $H$. bidorsalis fingerlings from the same broodstock (mean mass, $10 \pm 0.42 \mathrm{~g}$ ) obtained from the National Institute for Freshwater Fisheries Research hatchery, New-Bussa, Niger State, Nigeria were used. The fingerlings were acclimated to laboratory conditions for 14 days before being distributed randomly among 15 aquarium tanks (40-litre capacity) at 15 fish per aquarium $(60 \mathrm{~cm} \times 30 \mathrm{~cm} \times 30 \mathrm{~cm})$. The experimental treatments represented by four feeding rations were tested in triplicate.

\section{Feed ingredients and preparation of artificial feed}

The detail of feed ingredients and proximate composition is given in Table 1. These ingredients were ground to a small particle size $(3.0 \mathrm{~mm})$. Ingredients including vitamin premix were thoroughly mixed in a Hobbart A- 2007 pelleting and mixing machine (Hobart Ltd London, England) to obtain a homogenous mass, and cassava starch was added as a binder. The resultant mash was then pressed without steam through a mixer with $0.9 \mathrm{~mm}$ die attached to the Hobart pelleting machine. The produced pellets were dried at ambient temperature of $27{ }^{\circ} \mathrm{C}-30{ }^{\circ} \mathrm{C}$ and packed in plastic bags and stored.

\section{Experimental setup}

The design utilized fifteen aquarium tanks $(60 \mathrm{~cm} \times 30 \mathrm{~cm} \times 30 \mathrm{~cm})$ of 40 -litre capacity. A water volume of $26 \mathrm{~L}$ was maintained in each tank. Continuous aeration was provided in all the tanks using Tecax air pump model AP 3000. Prior to the feeding of the experimental diets, the fish were starved overnight. The fish were fed with experimental feed $40 \%$ crude protein at $4 \%$, $6 \%, 8 \%$ and $10 \%$ body weight, twice a day during morning (08:00 hr) and afternoon (18:00 hr) for 7 weeks and quantity of feed introduced adjusted to mean fish weight in each aquarium tank..

At the beginning of the experiment, pooled samples of 15 fish (fingerlings) samples were randomly taken for carcass composition and at the end of the experiment pooled samples of 15 fish were randomly taken from each treatment for carcass composition using AOAC (1997) procedures. All treatments were tested in triplicate where each aquarium tank was considered as an experimental unit.

Water quality parameters such as temperature, $\mathrm{pH}$ and dissolved oxygen concentration were studied on daily basis using standard methods as described by APHA (1998) using a thermometer for temperature $\left({ }^{\circ} \mathrm{C}\right), \mathrm{pH}$ meter (Hanna H198106 model) and dissolved oxygen meter (JP 607 model). 


\section{Fish growth studies}

The fishes were monitored individually for their total body weight ( $\mathrm{g}$ ) after every two weeks for 7 weeks. The data: Weight gain (WG), specific growth rate (SGR), food conversion ratio (FCR) and protein efficiency ratio (PER) were calculated by following formulae:

WG = Final weight $(\mathrm{g})-$ Initial weight $(\mathrm{g})$.

SGR = (ln final body weight - Initial body weight) $\times 100 /$ No. of days of experiment.

FCR = Feed given $(\mathrm{g}) /$ Wet weight gain $(\mathrm{g})$.

PER = Live body weight gained $(\mathrm{g}) /$ Protein intake $(\mathrm{g})$.

Where: Protein Intake $(\mathrm{g})=$ Protein $(\%)$ in feed $\times$ Feed given $(\mathrm{g}) / 100$.

Survival rate $(\%)=$ Number of surviving fish $/$ Number of fish at the beginning $\times 100$.

\section{Statistical analysis}

The values were recorded as mean \pm standard deviation. The statistical significance of difference in the mean and standard deviation $(\mathrm{P}<0.05)$ was analyzed by one-way ANOVA test comparison of each of the test groups and the control using the SPSS 15 . Duncan's multiple range was used to compare differences among individual means (Zar, 1984). Differences were considered significant at $\mathrm{p}$ levels $<0.05$.

\section{RESULTS AND DISCUSSION}

Mean water quality parameters during the experiment were $5.2-6.5 \mathrm{mg} / \mathrm{l}, 7.4-7.9$ and $27.00-27.50^{\circ} \mathrm{C}$ for dissolved oxygen, $\mathrm{pH}$ and temperature respectively. These were within optimal limits for production of African catfish (Viveen et al., 1986). Loss of fish was attributed to the physical stress to which they were subjected during samplings.
Feeding rate significantly $(\mathrm{P}<0.05)$ affected the SGR, FCR, PER and ADG. Data on growth and feed utilization performance is given in Table 2. Fish fed at $4 \%$ feeding ration had the best FCR and PER (Table 2), due to efficient conversion of the diet by $H$. bidorsalis at that feeding ration. There were improvements in the growth responses with increasing feeding ration up to $6 \%$ feeding ration. Thereafter, further improvements were not significant. The poorest growth rate was obtained in the $10 \%$ feeding ration, while the $6 \%$ feeding ration gave the highest growth performance values, followed by the $4 \%$ feeding ration. No significant differences $(\mathrm{P}>$ $0.05)$ were found between the growth of fish fed at $4 \%$ and $6 \%$ feeding ration.

Generally, low feed conversion ratio (FCR) were obtained in all treatments, but the poorest occurred in both $8 \%$ and $10 \%$ feeding rations (Table 2), although better FCR was obtained at $4 \%$ feeding ration, but there were no significant difference $(\mathrm{P}>0.05)$ between the FCR of fish fed $6 \%$ feeding ration. The PER decreased $(\mathrm{P}<0.05)$ with increased in feeding ration. Similar observations were reported for other fish species such as Cyprinus carpio, whitefish Coregonus lavaretus and Tilapia (GIFT) (Abdelghany and Ahmad, 2002; Wunderlich et al., 2011; Zikria et al., 2012).

Carcass composition (Table 3) shows an increased in crude protein and a decreased in fat contents as the feeding ration increased. Data on carcass composition followed the same trend as those of earlier studies, i.e. an increased in the body protein with an increased in the feeding ration (Pouomogne and Mbongblange, 1993; Dada et al., 2001).

Based on the results and the foregoing, it could be concluded that an intermediate feeding ration between $4 \%$ and $6 \%$ body weight per day is ideal for adequate growth and development of $H$. bidorsalis during culture period. 
Table 1: Ingredient composition ( $\mathrm{kg}$ ) and proximate composition (\% DM) of basal diet.

\begin{tabular}{|c|c|}
\hline Ingredients & g/kg diet \\
\hline$\overline{\text { Fish meal }}$ & 14.70 \\
\hline Soybean meal & 54.10 \\
\hline Blood meal & 4.70 \\
\hline Yellow maize & 25.00 \\
\hline Vegetable oil & 1.00 \\
\hline Vitamin-mineral premix & 0.50 \\
\hline Corn starch & 1.00 \\
\hline \multicolumn{2}{|c|}{ Proximate composition (\%) } \\
\hline Crude protein & 40.4 \\
\hline Crude lipid & 17.4 \\
\hline Ash & 12.1 \\
\hline Gross energy $(\mathrm{MJ} / \mathrm{Kg})$ & 16.9 \\
\hline
\end{tabular}

Table 2: Comparison of growth parameters of $H$. bidorsalis fingerlings at different rations (means are of three replicates with $n=15$ ).

\begin{tabular}{lcccc}
\hline Parameters & \multicolumn{4}{c}{ Ration levels (\% body weight) } \\
\hline Initial mean wt (g) & $\mathbf{4}$ & $\mathbf{6}$ & $\mathbf{8}$ & $\mathbf{1 0}$ \\
Final mean wt (g) & $10.12(0.51)^{\mathrm{a}}$ & $10.56(0.49)^{\mathrm{a}}$ & $10.48(0.38)^{\mathrm{a}}$ & $9.64(0.40)^{\mathrm{a}}$ \\
Mean wt gain (g) & $18.62(1.44)^{\mathrm{a}}$ & $19.44(1.46)^{\mathrm{a}}$ & $18.76(1.41)^{\mathrm{a}}$ & $14.09(0.74)^{\mathrm{b}}$ \\
SGR (\%/day) & $8.50(0.62)^{\mathrm{a}}$ & $8.88(0.40)^{\mathrm{a}}$ & $8.28(0.48)^{\mathrm{a}}$ & $4.45(0.28)^{\mathrm{b}}$ \\
ADG (g/day) & $0.87\left(0.00^{\mathrm{a}}\right.$ & $0.87(0.00)^{\mathrm{a}}$ & $0.83(0.01)^{\mathrm{a}}$ & $0.54(0.03)^{\mathrm{b}}$ \\
FCR & $0.12(0.01)^{\mathrm{a}}$ & $0.13(0.02)^{\mathrm{a}}$ & $0.12(0.01)^{\mathrm{a}}$ & $0.06(0.00)^{\mathrm{b}}$ \\
PER & $1.67(0.01)^{\mathrm{a}}$ & $1.93\left(0.02^{\mathrm{a}}\right.$ & $2.93(0.03)^{\mathrm{b}}$ & $6.73(0.01)^{\mathrm{c}}$ \\
\% survival & $0.24(0.00)^{\mathrm{a}}$ & $0.16(0.01)^{\mathrm{b}}$ & $0.14(0.01)^{\mathrm{b}}$ & $0.06(0.00)^{\mathrm{c}}$ \\
\hline
\end{tabular}

Mean in a given column with the same letter were not significantly different at $\mathrm{p}<0.05$. Values in parentheses are standard errors of mean values. 
Table 3: Chemical composition of whole body of $H$. bidorsalis fingerlings fed at different feeding rations (as wet basis).

\begin{tabular}{lcccc}
\hline & \multicolumn{5}{c}{ Experimental Feeding rations (\% body weight) } \\
\cline { 2 - 5 } Composition (\%) & $\mathbf{4}$ & $\mathbf{6}$ & $\mathbf{8}$ & $\mathbf{1 0}$ \\
\hline Moisture & $8.73(0.06)^{\mathrm{a}}$ & $79.73(0.04)^{\mathrm{a}}$ & $79.87(0.09)^{\mathrm{a}}$ & $77.48(0.02)^{\mathrm{a}}$ \\
Protein & $13.75(0.02)^{\mathrm{b}}$ & $14.70(0.04)^{\mathrm{b}}$ & $15.40(0.02)^{\mathrm{c}}$ & $16.80(0.03)^{\mathrm{d}}$ \\
Lipid & $3.54(0.01)^{\mathrm{b}}$ & $3.43(0.01)^{\mathrm{b}}$ & $3.04(0.02)^{\mathrm{c}}$ & $3.05(0.01)^{\mathrm{c}}$ \\
Ash & $1.87(0.01)^{\mathrm{b}}$ & $2.14(0.04)^{\mathrm{b}}$ & $2.33(0.14)^{\mathrm{b}}$ & $2.67(0.24)^{\mathrm{c}}$ \\
\hline
\end{tabular}

Initial moisture, 85.7(0.06), crude protein, 10.75(0.02), crude lipid, 2.03(0.02), ash, 1.49(0.01). Values in the same row with common superscripts are not significantly Different $(\mathrm{P}<0.05)$. Values in parentheses are standard errors of mean values.

\section{ACKNOWLEDGEMENTS}

This study was funded by the National Institute for Freshwater Fisheries Research, New - Bussa, Niger State, Nigeria.

\section{REFERENCES}

Abdelghany AE, Ahmad MH. 2002. Effects of feeding rates on growth and production of Nile tilapia, common carp and silver carp polycultured in fertilized ponds. Aquacult. Research., 33: 415-423.

Abdel-Hakim NF, Abo State HA, Al-Azab AA, El-Kholy KhF. 2009. Effect of feeding regimes on growth performance of juvenile hybrid tilapia (Oreochromis niloticus $\times$ Oreochromis aureus). $W . J$. Agric. Sci., 5: 49-54.

AOAC. 1997. Official Methods of Analysis $\left(16^{\text {th }}\right.$ edn). Association of Official Analytical Chemists.

APHA. 1998. Standard Method for the Examination Water and Wastewater (20th edn), Cunniff PA (ed). American Public Health Association, the American Water Works Association and the Water Environment: Arlington, V.A; 1141.

Dada AA, Fagbenro OA, Ita EO. 2001. Effects of Different Feeding Levels on the production of Heterobranchus bidorsalis in outdoor concrete tanks. Journal of Aquaculture in the Tropics, 16(1): 23-28.

Desilva SS, Anderson TA. 1995. Fish Nutrition in Aquaculture. Chapman and Hall Aquaculture.

Eroldogan OT, Kumlu M, Kiris GA, Sezer B. 2006. Compensatory growth response of Sparus awrata following different starvation and refeeding protocols. Aquacult. Nutri., 12(1): 203-210.

Effect of feeding regime in fingerling culture. Aquaculture, 34: 265-285.

Le VK, Fotedar R, Kumar MS. 2012. Effects of feeding rates on the growth, water quality and nutrient budget of western king prawn (Penaeus latisulcatus Kishinouye) reared in recirculating aquaculture systems. Aquacult. Research. doi: 10.1111/j. 1365 -2109. 2012.0312.0x

Pouomogne V, Mbongblange J. 1993. Effect of feeding rate on the growth of Tilapia (Oreochromis niloticus) in earthen ponds. The Israeli Journal of AquacultureBamidgeh, 45(4): 147-153.

Santiago GB, Aldaba MB, Reyes OS. 1987. Influence of feeding rate and diet form on growth and survival of Tilapia (Oreochromis niloticus) fry. Aquaculture, 64: 277-287. 
Rad F, Koksal G, Kindir M. 2003. Growth performance and food conversion ratio of Siberian sturgeon (Acipencer baeri Brandt) at different daily feeding rates. Turk. J. Vet.Anim. Sci., 27: 1085-1090.

Viveen WJAR, Richter CJJ, Van Oordt PG, Janssen JAL, Huisman EA. 1986. Practical manual for the African Catfish, Clarias gariepinus. Section for Research and Technology, Box 20061, 2500EB. The Haque, Netherlands.

Wunderlich K, Szczepkowska B, Szczepkowski M, Kozlowski M, Piotrowska I. 2011. Impact of daily feed rations for juvenile common whitefish
Coregonus lavaretus (L.), on rearing indicators and oxygen requirements. Arch. Pol. Fish., 19: 23-30.

Zar JH (1984). Biostastistical Analysis. Prentice-Hall, Englewood Cliffs: New Jersey, USA.

Zikria N, Khan N, Mughal MS, Ashraf M, Khalique A, Alam S, Tayyab R. 2012. Effect of different ration levels of artificial feed on the growth performance of genetically improved farmed tilapia (GIFT) fry. Pakistan J. Sci., 64: 219-222. 